\title{
Clinical and systemic management of myiasis in a patient with advanced Alzheimer's disease
}

Manejo clínico e sistêmico de miliase em paciente com doença de Alzheimer avançada

Manejo clínico y sistémico de la miasis en un paciente con enfermedad de Alzheimer avanzada

Received: 02/20/2021 | Reviewed: 02/27/2021 | Accept: 03/02/2021 | Published: 03/08/2021

William Phillip Pereira da Silva ORCID: https://orcid.org/0000-0003-4172-7217

São Paulo State University, Brazil

E-mail: william_phillip@hotmail.com

Stéfany Barbosa

ORCID: https://orcid.org/0000-0002-4190-7931

São Paulo State University, Brazil

E-mail: stefanybarbosa61.sb@gmail.com

Bruno Coelho Mendes

ORCID: https://orcid.org/0000-0001-7896-8909

São Paulo State University, Brazil

E-mail: bruno.c.mnds@gmail.com

Mateus Diego Pavelski

ORCID: https://orcid.org/0000-0002-1691-390X

São Paulo State University, Brazil

E-mail: mateus_pavelski@hotmail.com

Anderson Maikon de Souza Santos

ORCID: https://orcid.org/0000-0001-9371-9417

São Paulo State University, Brazil

E-mail: andersonmaikon@ @otmail.com

Mirela Caroline Silva

ORCID: https://orcid.org/0000-0002-9455-3807 São Paulo State University, Brazil

E-mail: mirela_carol12@hotmail.com

João Matheus Fonseca e Santos

ORCID: https://orcid.org/0000-0002-2021-778X

São Paulo State University, Brazil

E-mail: jmfs215@gmail.com

Osvaldo Magro Filho

ORCID: https://orcid.org/0000-0002-9821-2479

São Paulo State University, Brazil

E-mail: osvaldo.magro@unesp.br

Leonardo Perez Faverani

ORCID: https://orcid.org/0000-0003-2249-3048

São Paulo State University, Brazil

E-mail: Leonardo.faverani@unesp.br

\begin{abstract}
The management of patients with neurodegenerative conditions such as Alzheimer's disease presents a challenge in promoting oral health, which is mainly linked to the motor and cognitive limitations that these individuals have, making them susceptible to the development of a series of oral diseases, such as oral myiasis. The presence of larvae in the oral cavity in patients with Alzheimer's disease seems to be related to poor oral hygiene condition, to the long periods that the patient remains immobile and with the mouth ajar, facilitating the deposition of eggs. Therefore, this study aimed to report a clinical experience of a patient with Alzheimer's disease in an advanced stage and with manifestation of oral myiasis on the oral floor, vestibule bottom and inserted gum. The 81-year-old patient was debilitated, bedridden, unable to perform his activities alone, was taken to the emergency room by his caregiver, who reported having noticed the presence of larvae in the oral cavity. The patient was hospitalized and immediately administered Ivermectin, ceftriaxone and clindamycin. On the second day of hospitalization, he presented a systemic worsening due to bronchoaspiration, requiring immediate removal of the larvae under local anesthesia. Only after significant improvement in the general condition, thorough surgery was performed to debridement of the injured areas and remnants of larvae. After hospital discharge with 2-month follow-up, the patient did not have any complications related to his oral health, demonstrating that periodic follow-up to debilitated patients is an important tool for preventing opportunistic manifestations such as oral myiasis.
\end{abstract}

Keywords: Alzheimer's disease; Oral health; Myiasis. 


\begin{abstract}
Resumo
O manejo de pacientes com condições neurodegenerativas como a doença de Alzheimer apresenta-se um desafio na promoção de saúde bucal, o que está atrelado principalmente as limitações motoras e cognitivas que tais indivíduos possuem, tornando-os susceptíveis ao desenvolvimento de uma série de doenças bucais, como a miíase oral. A presença de larvas na cavidade oral em pacientes com doença de Alzheimer parece estar relacionada a condição de higiene bucal deficiente, aos longos períodos que o paciente permanece imóvel e com a boca entreaberta, facilitando a deposição dos ovos. Diante disso, este trabalho teve o objetivo de relatar uma experiência clínica de paciente com doença de Alzheimer em estágio avançado e com manifestação de miíase oral em assoalho bucal, fundo de vestíbulo e gengiva inserida. $\mathrm{O}$ paciente de 81 anos encontrava-se debilitado, acamado, sem condições de realizar suas atividades sozinho, foi levado ao pronto atendimento por sua cuidadora, que relatou ter notado presença de larvas em cavidade bucal. O paciente foi internado e imediatamente instituiu-se administração de Ivermectina, ceftriaxona e clindamicina. No segundo dia de internação, apresentou uma piora sistêmica devido broncoaspiração, necessitando de remoção imediata das larvas sob anestesia local. Somente após significativa melhora da condição geral, realizou-se cirurgia minuciosa para debridamento das áreas lesionadas e de remanescentes de larvas. Após alta hospitalar com acompanhamento de 2 meses, o paciente não apresentou nenhuma intercorrência relacionada a sua saúde bucal, demonstrando que o acompanhamento periódico a pacientes debilitados é uma ferramenta importante para prevenção de manifestações oportunistas como a miíase oral.
\end{abstract}

Palavras-chave: Doença de Alzheimer; Saúde bucal; Miíase.

\title{
Resumen
}

El manejo de pacientes con afecciones neurodegenerativas como la enfermedad de Alzheimer presenta un desafío en la promoción de la salud bucal, que está principalmente ligado a las limitaciones motoras y cognitivas que tienen estos individuos, haciéndolos susceptibles al desarrollo de una serie de enfermedades bucodentales. La presencia de larvas en la cavidad oral en pacientes con enfermedad de Alzheimer parece estar relacionada con un mal estado de higiene bucal, con los largos periodos que el paciente permanece inmóvil y con la boca entreabierta, facilitando el depósito de huevos. Este estudio tuvo como objetivo reportar una experiencia clínica de un paciente con enfermedad de Alzheimer en estadio avanzado y con manifestación de miasis oral en el piso bucal, fondo del vestíbulo y encía insertada. El paciente de 81 años se encontraba debilitado, postrado en cama, incapaz de realizar sus actividades solo, fue llevado a urgencias por su cuidador, quien refirió haber notado la presencia de larvas en la cavidad bucal. El paciente fue hospitalizado y se le administró inmediatamente ivermectina, ceftriaxona y clindamicina. Al segundo día de hospitalización presentó un agravamiento sistémico por broncoaspiración, requiriendo la extracción inmediata de las larvas bajo anestesia local. Solo después de una mejora significativa en el estado general, se realizó una cirugía completa para el desbridamiento de las áreas lesionadas y los restos de larvas. Tras el alta hospitalaria con seguimiento a 2 meses, el paciente no presentó complicaciones relacionadas con su salud bucal, demostrando que el seguimiento periódico a pacientes debilitados es una herramienta importante para prevenir manifestaciones oportunistas como la miasis oral.

Palabras clave: Enfermedad de Alzheimer; Salud bucal; Miasis.

\section{Introduction}

The management and care of oral hygiene in patients with physical, and, or mental limitations, present themselves as a challenge in health promotion. Due to the limitation of motor and cognitive abilities, the patient becomes unable to perform oral care on his own, and he must be is accompanied by caregivers or family members who routinely perform such cleanliness, so that the individual's health is maintained (Ribeiro et al., 2012).

The general health of patients with mental health problems, cerebral palsy, epilepsy, alcoholism, senility, and Alzheimer's disease in more advanced stages of the disease, are much more susceptible to cavities, periodontal diseases, infections, etc., precisely because of this difficulty hygiene management (Mengi et al., 2015). Alzheimer's disease is a progressive neurodegenerative disease, which can reach two or more cognitive domains, such as memory, language, spatial and temporal location, personality, and behavior. Patients in advanced stages of those diseases are often reported with cases of oral myiasis (Weller \& Budson, 2018)(Sengoku, 2020).

Myiasis corresponds to a condition caused by dipteran larvae, which develop predominantly in tropical and subtropical regions (de Souza Barbosa et al., 2008). Myiasis occurs when a fly lays its eggs in injured tissue, in skin or mucosa, which hatch in larvae, which start to act as parasites, feeding on healthy or necrotic tissues, liquid substances, or even the food 
that the host ingest (Thyssen et al., 2012). With that, they go deeper into the soft tissues, so that in more severe conditions, they can cause injuries even in cartilage and bone tissue (Ribeiro et al., 2012).

Being a rare condition in healthy individuals, local predisposing factors such as poor oral hygiene, periodontal pockets, tooth extraction wounds, mouth breathing, absence of lip sealing, presence of suppurative lesions, anterior open bite, halitosis, presence of ulcers and malignant tumors developing, favor the deposition of eggs in the oral mucosa, leading to the development of larvae (de Arruda et al., 2017; Droma et al., 2007). Other factors should also be considered, such as socioeconomic factors, since debilitated patients from humbler families are at greater risk of suffering neglect and abandonment, and the environmental factor, considering that the occurrence of myiasis is greater in hot and humid regions, (de Arruda et al., 2017; Filho et al., 2018).

Clinically, oral myiasis can be characterized by the presence of pain, fever, marked odor, local discomfort, inflammation of the region and surrounding tissues, presence of ulcerations, and tissue necrosis, which can extend to bone tissue (Abdo et al., 2006; Cavalcanti, 2008; Gross \& Jitumori, 2019). The diagnosis of this condition is clinical, due to the presence of larvae interspersed with the oral tissues, however, in some cases, it is possible to perform surgical exploration and histopathological examination as a means of complement (Freitas et al., 2012). The recommended treatment is the mechanical removal of the larvae, debridement of the necrotic regions, prescription of the antiparasitic Ivermectin, and, in some cases, the administration of antibiotics to prevent secondary infections (de Souza Barbosa et al., 2008; Filho et al., 2018).

Therefore, this study aims to report the occurrence of oral myiasis in an elderly patient with advanced Alzheimer's disease, discussing clinical management and demonstrating the need for preventive care for the development of this condition.

\section{Methodology}

A descriptive and qualitative interventional study was carried out (Pereira et al., 2018) case study, which was authorized by the patient and his family using an Informed Consent Term (ICT), prepared with easy to understand language so that they were aware of the destination of the personal information collected, as well as the associated risks and benefits. Also, a brief review of the literature was carried out, through the search for scientific articles and case studies, as a basis for the information described here, for this, searches were performed in the MEDLINE database, on the PubMed portal and Google Scholar, through the keywords "Myiasis" and "Alzheimer's disease".

\section{Results}

An 81-year-old male patient with advanced Alzheimer's disease, type 2 diabetes mellitus, systemic arterial hypertension, cardiac arrhythmia, hypercholesterolemia, with motor restrictions and lack of lucidity, attended the hospital emergency room, bedridden and accompanied by his caregiver, who reported the perception of the presence of larvae in the oral cavity started 2 days ago. In the extra-oral physical examination, mild edema in the mentonian region and marked halitosis from the oral cavity were observed, and in the intra-oral examination, the presence of larvae in the oral floor, vestibule bottom, and inserted gums was noted.

As conduct, the patient's hospitalization required multidisciplinary care in conjunction with neurology and cardiology specialties. Initially, Ivermectin ( $200 \mu \mathrm{g} / \mathrm{kg}$, subcutaneous), ceftriaxone (500mg intravenous), and clindamycin (intravenous) were administered, in addition to the patient's continuous routine medications, Losartan 50mg, Diamicron MR 60mg, Alprozolan 2mg, and 10.5mg, Sotalol 160mg, Donepezila 10mg, Glifage XR 500mg, Atorvastatin 10mg, Neorine 4mg \%, and Patz SL 5mg. 
On the second day of hospitalization, the patient presented a decrease in the level of consciousness, vomiting, acute respiratory failure, and oxygen desaturation, due to bronchoaspiration, presenting the need for sedation and orotracheal intubation for mechanical ventilation in the Cardiac Intensive Care Unit. With the worsening of the patient's general systemic condition, the removal of the larvae needed to be carried out in bed quickly (Figure 1). 72 hours after the administration of Ivermectin, the larvae were no longer present (Figure 2).

Figure 1 - Clinical images of the presence of larvae in the anterior buccal floor region, demonstrating great tissue impairment and exacerbated number of larvae at risk of aspiration.

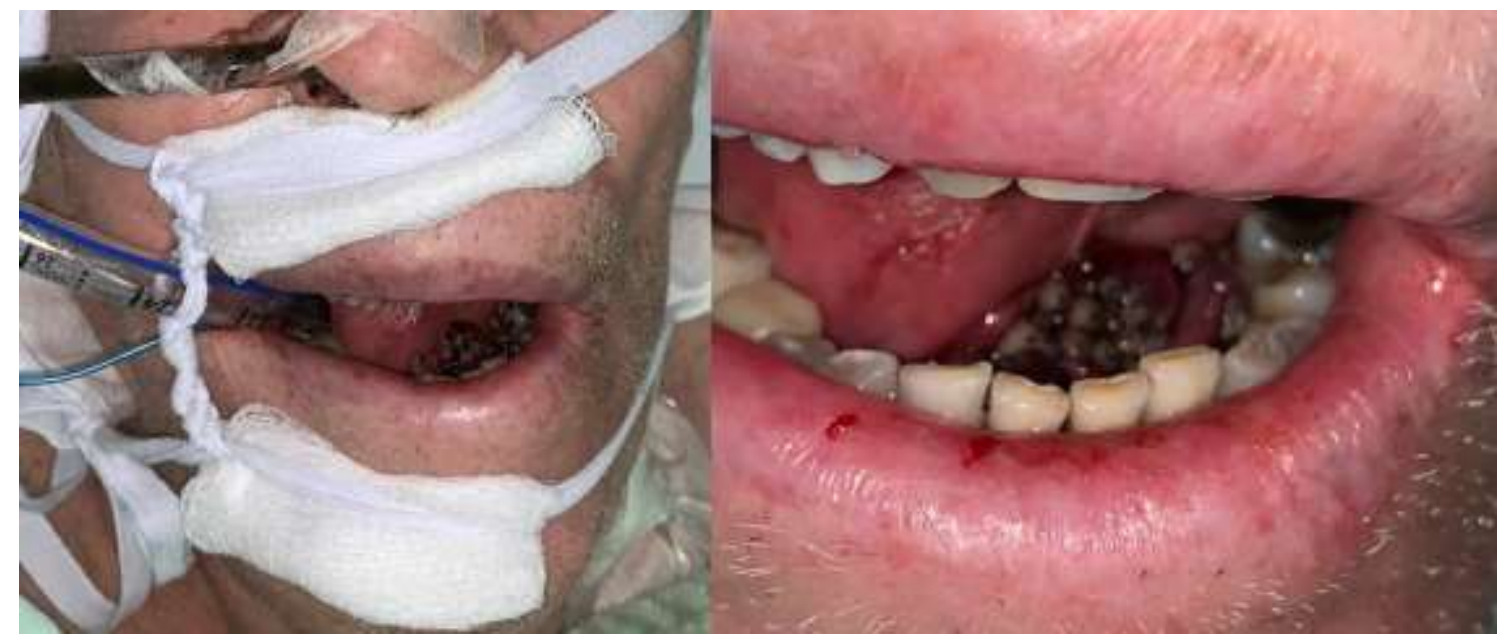

Source: Authors

Figure 2 - Mechanical removal of larvae and immediate debridement of all necrotic tissue.

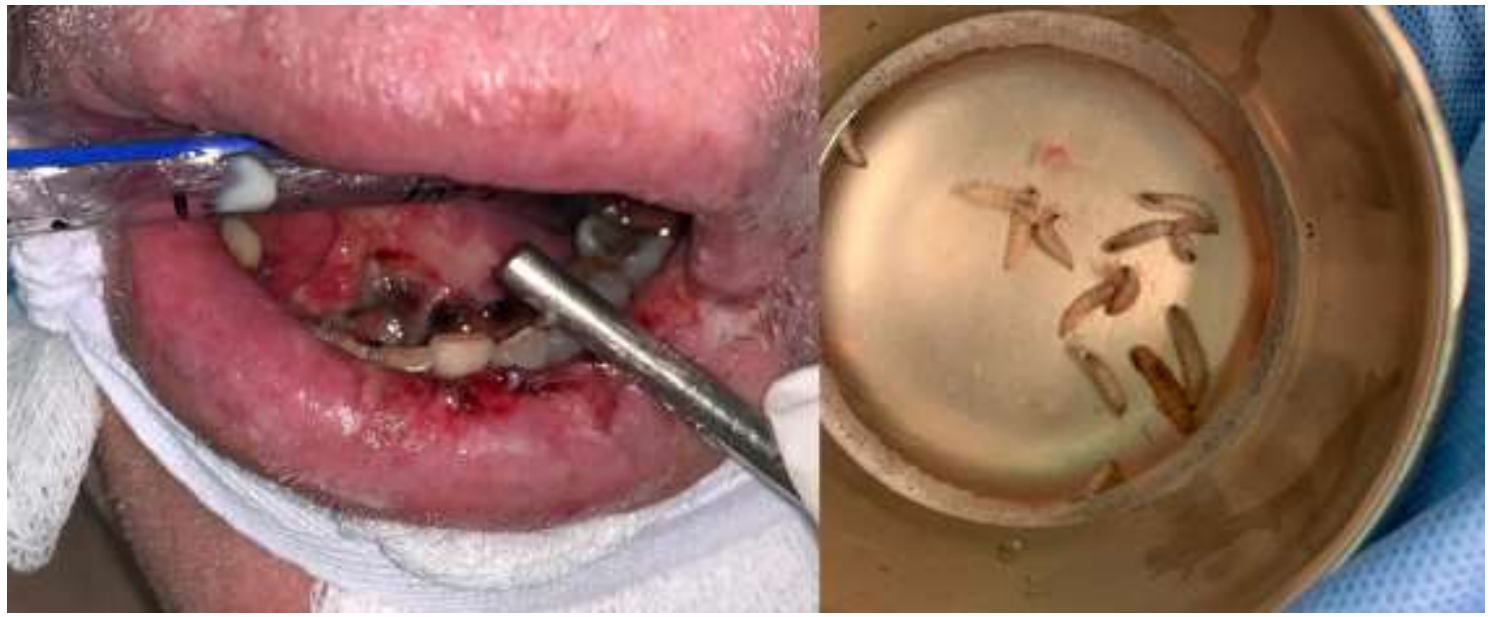

Source: Authors

On the ninth day of hospitalization, the patient presented better in systemic conditions, and a rigorous surgical debridement can be performed under general anesthesia. During the surgical treatment, there was no presence of larvae in the affected region, with debridement and primary closure of the affected region being performed. Due to the patient's oral conditions, with periodontal problems, coronary destruction, and the condition of restricted movement and difficulty in maintaining oral hygiene, it was necessary to perform a total extraction, removing the infectious focus (Figures 3 and 4 ). 
Figure 3 - Clinical images of the patient's poor oral hygiene, with the presence of stones, bone loss and periodontal pockets.

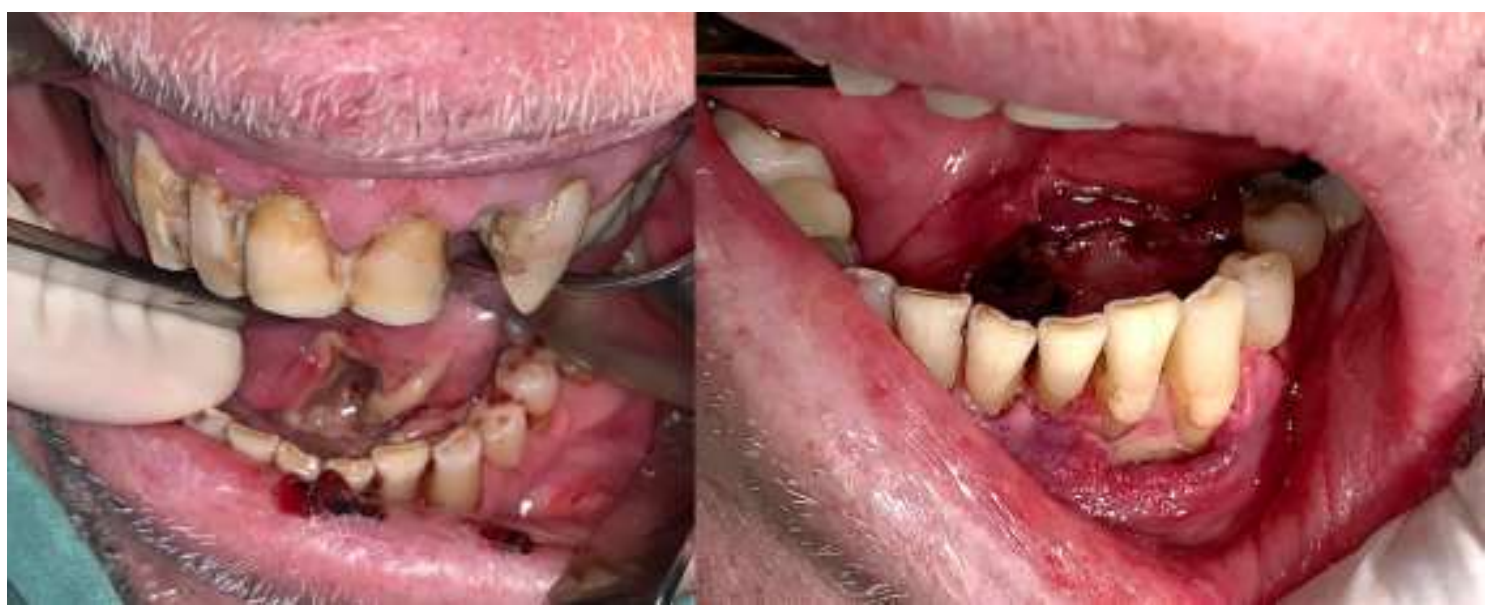

Source: Authors

Figure 4 - Images of trans-surgical approaches for debridement of the wound affected by myiasis. Immediate postoperative period, after total extraction and tissue closure, as a method of removing the foci of infections that attract flies.

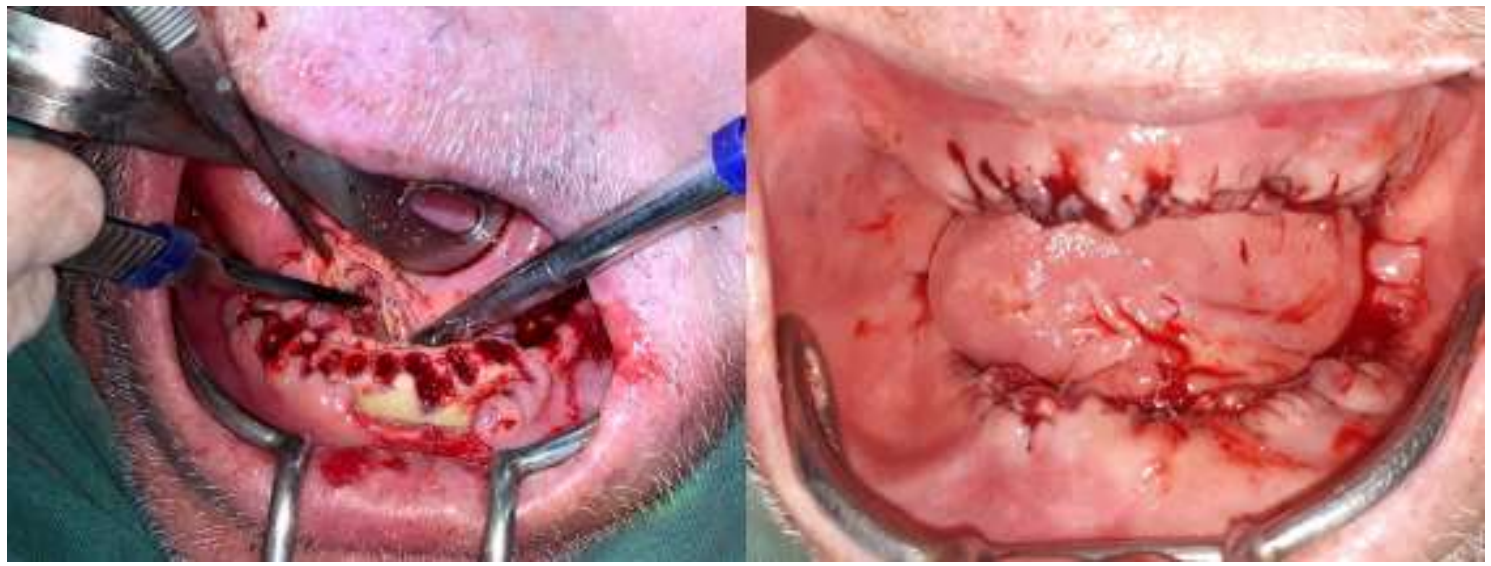

Source: Authors

On the fourth postoperative day, due to good systemic and local evolution, the patient was discharged. Two months after hospital discharge, the patient died due to his systemic condition, but during this time of follow-up, there was no oral change after the treatment was performed.

\section{Discussion}

The increase in the prevalence of neurodegenerative diseases, such as Alzheimer's disease, is linked to the increase in life expectancy and the increase in the elderly population worldwide. In advanced stages of this disease, the patient becomes very weak and dependent to do their daily tasks, including performing oral health care. (Ribeiro et al., 2012). Poor oral hygiene promotes the development of periodontic pathogenic microorganisms, as well as the occurrence of injuries, which can develop without the patient having any complaints, due to severe cognitive loss.

The excessive halitosis produced by the products of oral microorganisms ends up attracting the flies of the species Cochliomyia hominivorax, which may have their entry facilitated by the presence of anterior open bite and absence of lip sealing (Filho et al., 2018). An important factor for the development of myiasis in living humans is that it is significantly immobilized for a long period, allowing the fly to lay its eggs (Werminghaus et al., 2008). Due to the patient's clinical status, 
even with a strong presence and assistance from a caregiver, limited movement and daily difficulty in maintaining oral hygiene, were important factors in the development of myiasis in the patient-reported in our study.

Although worms leave the host after maturation, myiasis can cause serious complications and even be fatal (Werminghaus et al., 2008). Among the reported complications, there are extensive tissue destruction, palatal perforation, and thrombosis of the cavernous sinus. Blindness, hearing loss, problems with salivary glands, oroantral communication, and loss of considerable parts of soft tissues and bones, have also been described as sequelae of the occurrence of myiasis in orofacial regions (de Arruda et al., 2017). Besides, it is important to consider the risk of bronchoaspiration, as occurred in our clinical case[A1], causing a worsening of the clinical picture, due to respiratory failure and oxygen desaturation, which was immediately referred to the Intensive Care Unit to reestablish the airways. The bronchoaspiration of foreign bodies can also establish severe pneumonia, especially if there are already previous lung injuries (Naz et al., 2018).

The main treatment of myiasis is the mechanical removal of the larvae, under local or general anesthesia, according to the severity of the infestation and the general condition of the patient. As an adjuvant in the treatment, the administration of the antiparasitic Ivermectin, has fast action, acting in blocking the nerve impulses in the nerve endings of the parasites, leading them to paralysis and death (Shinohara et al., 2004). In the present study, it was started with the administration of Ivermectinia to later perform the surgical approach, however, with the worsening of the patient's systemic condition, previous administration of the medication was essential for the treatment since it was not possible to perform surgical removal and debridement. as soon as possible. Carefully remove each of the larvae, followed by the debridement of all necrotic areas, is subsequently avoided, the occurrence of inflammatory reactions and foreign bodies (Zhang et al., 2020).

Another therapeutic option is nitrofurazone administered topically, that is, it must be placed directly on the wound so that the larvae present come into contact with the liquid substance which, being offensive, will force them to leave the interior of the tissue and thus facilitate its removal (Filho et al., 2018). Other chemical agents have also been described in the literature to stimulate the larvae to leave the wound through tissue hypoxia or by the mechanical action produced by irrigation, such as saline, hydrogen peroxide, chlorhexidine, and gentian violet. (de Arruda et al., 2017; Filho et al., 2018).

Because of the risk factors for the development of oral myiasis, it is important that patients with debilitating conditions, such as Alzheimer's disease, undergo preventive procedures, with the removal of the possible focus of infections and periodic evaluation with the dental surgeon for maintenance of oral health. An interesting measure of collective prevention would be the installation of screens on windows and doors of dependencies that shelter patients considered at risk, to prevent the entry of flies that could deposit their eggs in favorable places for the development of the larvae. (Ribeiro et al., 2012). Also, one should always avoid leaving open wounds, ulcerations with necrotic tissue and infected areas, as well as performing good individual and environmental hygiene daily. To maintain these measures, the caregivers and family members of the patients must always remain oriented and supported, so that they know how to perform ideal oral hygiene and that they are attentive to any oral alteration that may serve as a gateway to the larvae infestation. (Simon et al., 2018).

\section{Conclusion}

Despite being an uncommon condition in the oral cavity, myiasis can generate major complications and sequelae, being extremely important that patients with debilitating conditions, such as Alzheimer's disease receive periodic attention to their oral health, avoiding having an environment conducive to the development of the larvae that cause this condition.

\section{References}

Abdo, E. N., Sette-Dias, A. C., Comunian, C. R., Dutra, C. E. A., \& Aguiar, E. G. (2006). Oral myiasis: A case report. Oral Medicine and Pathology, 11, 130131. 
Research, Society and Development, v. 10, n. 3, e12110313145, 2021

(CC BY 4.0) | ISSN 2525-3409 | DOI: http://dx.doi.org/10.33448/rsd-v10i3.13145

Cavalcanti, A. L. (2008). Miíase Oral: etiologia, diagnóstico e tratamento. Rev. Fac. Odontol. Porto Alegre, 49, 32-35.

de Arruda, J. A. A., de Oliveira Silva, L. V., Silva, P. U. J., de Figueiredo, E. L., Callou, G., Mesquita, R. A., \& do Egito Vasconcelos, B. C. (2017). Head and neck myiasis: a case series and review of the literature. Oral Surgery, Oral Medicine, Oral Pathology and Oral Radiology, 124(5), e249-e256. https://doi.org/10.1016/j.oooo.2017.06.120

de Souza Barbosa, T., Salvitti Sá Rocha, R. A., Guirado, C. G., Rocha, F. J., \& Duarte Gavião, M. B. (2008). Oral infection by Diptera larvae in children: a case report. International Journal of Dermatology, 47(7), 696-699. https://doi.org/10.1111/j.1365-4632.2008.03725.x

Droma, E. B., Wilamowski, A., Schnur, H., Yarom, N., Scheuer, E., \& Schwartz, E. (2007). Oral myiasis: a case report and literature review. Oral Surgery, Oral Medicine, Oral Pathology, Oral Radiology, and Endodontics, 103(1), 92-96. https://doi.org/10.1016/j.tripleo.2005.10.075

Filho, A. O., Dias, D., Miranda, Á., \& Hebling, E. (2018). Oral myiasis in older adult with severe Alzheimer's disease. Special Care in Dentistry, 38(2), 99106. https://doi.org/https://doi.org/10.1111/scd.12277

Freitas, D. A., Moreira, G., Jones, K. M., \& Caldeira, A. P. (2012). Social exclusion and myiasis of the upper lip in a Brazilian rural resident. Rural and Remote Health, 12, 2188.

Gross, D. J., \& Jitumori, C. (2019). Miíase bucal em paciente em estado vegetativo: relato de caso. Journal of Health, 1, $2178-3594$.

Mengi, E., Demirhan, E., \& Arslan, I. B. (2015). Aural myiasis: case report. Northern Clinics of Istanbul, 1(3), 175-177. https://doi.org/10.14744/nci.2014.96967

Naz, H., Aslan, L., Sönmez Tamer, G., \& Naz, C. (2018). [Case of pneumonia associated sepsis accompaning pulmonary myiasis]. Mikrobiyoloji bulteni, 52(4), 439-443. https://doi.org/10.5578/mb.67395

Pereira, A. S., Shitsuka, D. M., Parreira, F. J., \& Shitsuka, R. (2018). Metodologia da pesquisa científica. Universidade Federal de Santa Maria.

Ribeiro, M. T. de F., Sanglard-Oliveira, C. A., Naves, M. D., Ferreira, E. F. e, Vargas, A. M. D., \& Abreu, M. H. N. G. (2012). Miíase bucal e doença de Alzheimer: relato de caso clínico . In Revista Brasileira de Geriatria e Gerontologia, 15, 805-811. .

Sengoku, R. (2020). Aging and Alzheimer's disease pathology. Neuropathology: Official Journal of the Japanese Society of Neuropathology, 40(1), 22-29. https://doi.org/10.1111/neup.12626

Shinohara, E. H., Martini, M. Z., Oliveira Neto, H. G. de, \& Takahashi, A. (2004). Oral myiasis treated with ivermectin: case report . In Brazilian Dental Journal. 15, 79-81. .

Simon, L., Delaunay, P., Martinez, J. P., Hubiche, T., \& Del Giudice, P. (2018). Intensive cutaneous myiasis due to Musca domestica in a patient with Alzheimer disease: a rare larval infestation in a temperate zone. Clinical and Experimental Dermatology, 43(3), 342-344. https://doi.org/10.1111/ced.13291

Thyssen, P. J., Nassu, M. P., Costella, A. M. U., \& Costella, M. L. (2012). Record of oral myiasis by Cochliomyia hominivorax (Diptera: Calliphoridae): case evidencing negligence in the treatment of incapable. Parasitology Research, 111(2), 957-959. https://doi.org/10.1007/s00436-012-2856-3

Weller, J., \& Budson, A. (2018). Current understanding of Alzheimer's disease diagnosis and treatment. F1000Research, 7. https://doi.org/10.12688/f1000research.14506.1

Werminghaus, P., Hoffmann, T. K., Mehlhorn, H., \& Bas, M. (2008). Aural myiasis in a patient with Alzheimer's disease. European Archives of Oto-RhinoLaryngology: Official Journal of the European Federation of Oto-Rhino-Laryngological Societies (EUFOS) : Affiliated with the German Society for OtoRhino-Laryngology - Head and Neck Surgery, 265(7), 851-853. https://doi.org/10.1007/s00405-007-0535-2

Zhang, T.-Z., Jiang, Y., Luo, X.-T., Ling, R., \& Wang, J.-W. (2020). Oral myiasis after cerebral infarction in an elderly male patient from southern China: A case report. World Journal of Clinical Cases, 8(24), 6499-6503. https://doi.org/10.12998/wjcc.v8.i24.6499 